\title{
Analisis Alokasi Biaya Tetap Pada Penetapan Harga Pokok Unit Hunian di Tower 2 dan Tower 3 Apartemen Tamansari Prospero, Sidoarjo, Jawa Timur
}

\author{
Rahmawati Cahyaningsih dan Christiono Utomo \\ Jurusan Teknik Sipil, Fakultas Teknik Sipil dan Perencanaan, Institut Teknologi Sepuluh Nopember \\ J1. Arief Rahman Hakim, Surabaya 60111 \\ e-mail: cahyaningsihrahma@gmail.com, christiono@ce.its.ac.id
}

\begin{abstract}
Abstrak-Apartemen Tamansari Prospero terletak di Jl.Kahuripan Raya Kav 23-27, kawasan perumahan Kahuripan Nirwana Village, Sidoarjo, Jawa Timur. Terdiri dari 3 tower utama dengan 2 podium dimana tower 2 dan 3 masih tahap perencanaan sehingga diperlukan penetapan harga pokok produksi sebagai tahap awal perencanaan harga guna mempertahankan persaingan dengan harga yang ditawarkan oleh perumahan disekitar tapak. Tower 2 menawarkan tipe unit hunian studio, 1BR-A, 1BR-B dan 2BR. Tower 3 menawarkan tipe unit hunian studio, 1BR-A, 1BR-B, 2BR dan 3BR. Biaya tetap bersama seperti biaya lahan, pondasi, termasuk lift dan fasilitas kolam renang dan lainnya perlu dialokasikan dengan memperhatikan posisi unit secara vertikal dan horizontal. Menggunakan metode full costing, biaya total didapatkan dengan memperhitungkan semua unsur biaya pembangunan unit hunian, biaya tetap yang sudah dialokasikan dan biaya variabel.

Pengembalian biaya dalam penentuan harga pokok produksi (HPP) pada tingkat laba yang ditentukan yaitu sebesar $10 \%$, $20 \%$ dan $30 \%$. Didapatkan hubungan antara biaya tetap, biaya variabel, biaya total dan pendapatan pada tingkat laba yang ditetapkan dalam kurva biaya pada metode titik impas. Hasil penelitian ini didapatkan dengan melakukan alokasi biaya tetap berdasarkan posisi unit dengan asumsi laba yang ditetapkan, menghasilkan Harga Pokok Produksi (HPP) unit yang berbedabeda. HPP unit hunian di Tower 2, yaitu tipe studio berkisar 132jt-163jt. Tipe 1BR-A berkisar 199jt-244jt. Tipe 1BR-B berkisar 214jt-257jt. Tipe 2BR sekitar 265jt-326jt. HPP untuk tipe unit hunian di Tower 3, yaitu tipe studio berkisar 141jt-176jt. Tipe 1BR-A, 212jt-264 jt. Tipe 1BR-B, berkisar 227jt-278jt. Tipe 2BR, berkisar 282jt-352jt, dan 3BR berkisar 424jt- 528 jt.
\end{abstract}

Kata Kunci-Apartemen, harga pokok produksi, properti

\section{PENDAHULUAN}

A PARTEMEN Tamansari Prospero merupakan apartemen High Rise Building yang dikembangkan oleh PT.WIKA Gedung dan PT.Mutiara Masyhur Sejahtera, terletak di Jl.Kahuripan Raya Kav 23-27, kawasan perumahan Kahuripan Nirwana Village, Sidoarjo, Jawa Timur. Terdiri dari 3 tower utama, masing-masing tower 27 lantai dan 2 podium yang terdiri dari 6 lantai dengan fungsi mixed use (komersial dan residensial) menempati total luas tanah keseluruhan \pm 12.157 $\mathrm{m}^{2}$. Tower 1 sudah dibangun beberapa tahun lalu namun terdapat unit hunian didalamnya belum terjual. Tower 2 dan 3 masih tahap perencanaan sehingga diperlukan perencanaan ulang dalam penetapan harga unit hunian guna mempertahankan persaingan dengan harga yang ditawarkan oleh perumahan disekitar tapak.
Unit hunian pada tower 2 dan 3 dibedakan berdasarkan kelas ekonomi penghuninya sehingga terdapat perbedaan terhadap tipe unit hunian, fasilitas yang didapatkan serta interior didalamnya. Tower 2 diperuntukan untuk golongan menengah, dengan total 550 unit hunian, terdiri dari tipe studio, 1BR dan 2BR. Tower 3 diperuntukan untuk golongan menengah-atas, 476 unit dengan tipe unit hunian studio, 1BR, 2BR dan 3BR. Unit hunian mulai dari lantai 6-27 dan shopping centre sebagai area komersial berada di lantai 1-5 tower menyatu dengan kedua podium. Area komersial dilengkapi juga area parkir pada lantai semibasement dan sebagian area parkir di lantai 1-5 podium. Selain itu, terdapat fasilitas kolam renang yang berada pada lantai 6 podium disediakan khusus penghuni apartemen, dimana kolam renang pada podium 1 dapat diakses oleh penghuni apartemen tower 1 dan 2. Sedangkan fasilitas kolam renang pada podium 2 hanya dapat diakses penghuni tower 3 .

Pada umumnya calon pembeli akan mempertimbangkan posisi unit yang dekat dengan kolam renang serta kemudahan mobilisasi bagi penghuninya untuk beraktifitas. Agar semua unit memiliki potensi yang sama untuk dipilih calon pembeli, diperlukan strategi dalam penetapan harga secara proporsional dimana beban biaya setiap unitnya berbeda berdasarkan posisi unit. Biaya tetap bersama seperti biaya lahan, pondasi, termasuk lift, fasilitas kolam renang dan lainnya perlu dialokasikan dengan memperhatikan posisi unit secara vertikal dan horizontal. Semua biaya-biaya dalam pembangunan unit hunian, termasuk biaya tetap yang dialokasikan dan biaya variabel, perlu dikembalikan menjadi harga masing-masing unit. Perlu dilakukan peninjauan mengenai pengembalian biaya dalam penetapan harga pokok produksi (HPP) untuk masingmasing unit hunian tower 2 dan tower 3 dengan tingkat laba yang ditentukan yaitu sebesar $10 \%, 20 \%$ dan 30\%. Pada penelitian ini, biaya yang dikeluarkan untuk residensial tower 2 dan tower 3, akan dibantu area komersial sehingga harga unit hunian menjadi lebih murah. Biaya untuk pembangunan area komersial akan dibebankan kepada penyewa area komersial.

\section{PENELITIAN TERDAHULU}

Putra, Nurcahyo dan Utomo [1], Wahyudhi dan Utomo [2], Ningsih dan Utomo [3], Maulina dan Utomo [4], meneliti analisis investasi pada obyek yang sama dengan penelitian ini yaitu apartemen.

Fahad dan Utomo [5], Damayanti dan Utomo [6], Hidayat dan Utomo [7], Septiantoro dan Utomo [8], meneliti harga jual perumahan pada obyek yang sama yaitu unit rumah. Sedangkan 
Aprilia dan Utomo [9], meneliti harga jual apartemen pada obyek yang berbeda yaitu unit hunian apartemen namun menggunakan metode penelitian yang sama yaitu metode titik impas (Break Even Point) yang mempertemukan kurva biaya dan kurva pendapatan. Kurva biaya diperoleh dari perhitungan biaya tetap dan biaya variabel yang dibutuhkan. Kurva pendapatan diperoleh dari kurva permintaan yang diperoleh berdasarkan permintaan pasar disekitar obyek penelitian.

Utomo dan Utomo [10], meneliti harga pokok penjualan perumahan pada obyek unit rumah dengan melakukan alokasi biaya tetap yang berbeda-beda berdasarkan posisi rumah ditinjau secara horizontal. Metode yang digunakan adalah titik impas (Break Even Point) yang mempertemukan kurva biaya dan kurva pendapatan dengan skenario margin keuntungan pada setiap unit rumah yang dijual.

Hanundyasari dan Utomo [11], meneliti harga pokok penjualan apartemen pada obyek yang sama yaitu unit hunian di tower E dengan menggunakan metode titik impas (Break Even Point) yang mempertemukan kurva biaya dan kurva pendapatan. Dalam penelitian ini, kurva biaya diperoleh dari biaya tetap dan biaya variabel yang dihubungkan dengan asumsi margin profit pada dua skenario, yaitu biaya komersial dibebankan dan tanpa pembebanan biaya komersial.

Sembiring dan Utomo [12], meneliti harga pokok sewa apartemen pada obyek yang sama yaitu unit hunian apartemen menggunakan metode analisis titik impas (Break Even Point) yang mempertemukan kurva biaya dan kurva pendapatan. Kurva biaya diperoleh dari perhitungan biaya tetap dan biaya variabel yang dibutuhkan. Kurva pendapatan diperoleh dari rencana investasi dengan margin keuntungan yang ditetapkan yaitu $10 \%, 20 \%$, dan $30 \%$ pada setiap tipe per unit per tahun.

\section{METODOLOGI}

Penelitian ini dilakukan untuk menetapkan harga pokok produksi unit hunian apartemen Tamansari Prospero di Tower 2 dan Tower 3 seperti pada Gambar.1. Dilakukan alokasi biaya tetap yang berbeda-beda berdasarkan posisi unit hunian apartemen ditinjau secara vertikal dan horizontal. Metode yang digunakan adalah titik impas (Break Even Point) yang mempertemukan kurva biaya dan kurva pendapatan dengan margin keuntungan yang diinginkan untuk menutupi seluruh biaya-biaya produksi.

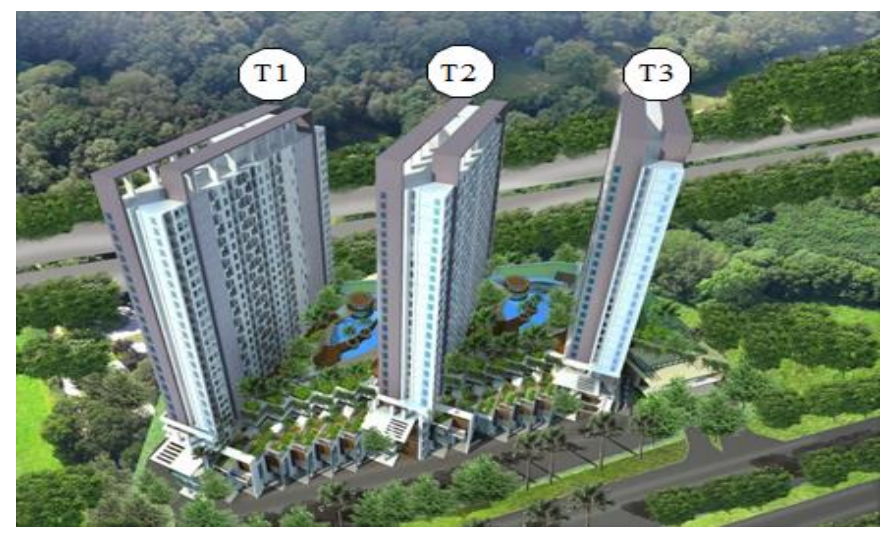

Gambar.1. Obyek Penelitian merupakan unit hunian di Tower 2 (T2) dan Tower 3 (T3).
Proses yang dilakukan dalam penelitian ini seperti Gambar.2. sebagai berikut :

\section{LATAR BELAKANG}

1.Obyek bersaing langsung dengan harga jual maupun sewa landed house disekitar tapak sehingga diperlukan penetapan harga.

2.Perlu alokasi biaya untuk biaya-biaya tetap yang digunakan bersama untuk seluruh unit

3.Pihak pengembang belum membangun maupun menetapkan harga unit abartemen tower 2 dan tower 3 .

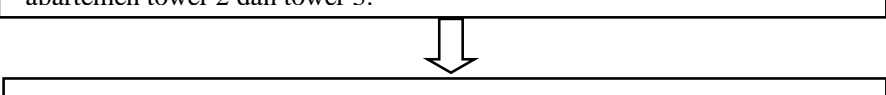

RUMUSAN MASALAH

Berapa Harga Pokok Produksi (HPP) masing-masing tipe unit apartemen pada tower 2 dan tower 3 pada Apartemen Tamansari Prospero dengan mempertimbangkan alokasi biaya tetap?

TUJUAN
Menganalisis alokasi biaya tetap pada penetapan Harga Pokok Produksi
(HPP) unit apartemen pada tower 2 dan tower 3 pada Apartemen
Tamansari Prospero, Sidoarjo, Jawa Timur.

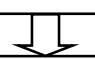

TINJAUAN PUSTAKA

Konsep pembebanan biaya, alokasi biaya, harga pokok produksi, klasifikasi apartemen dan penelitian terdahulu.

\section{$\perp$}

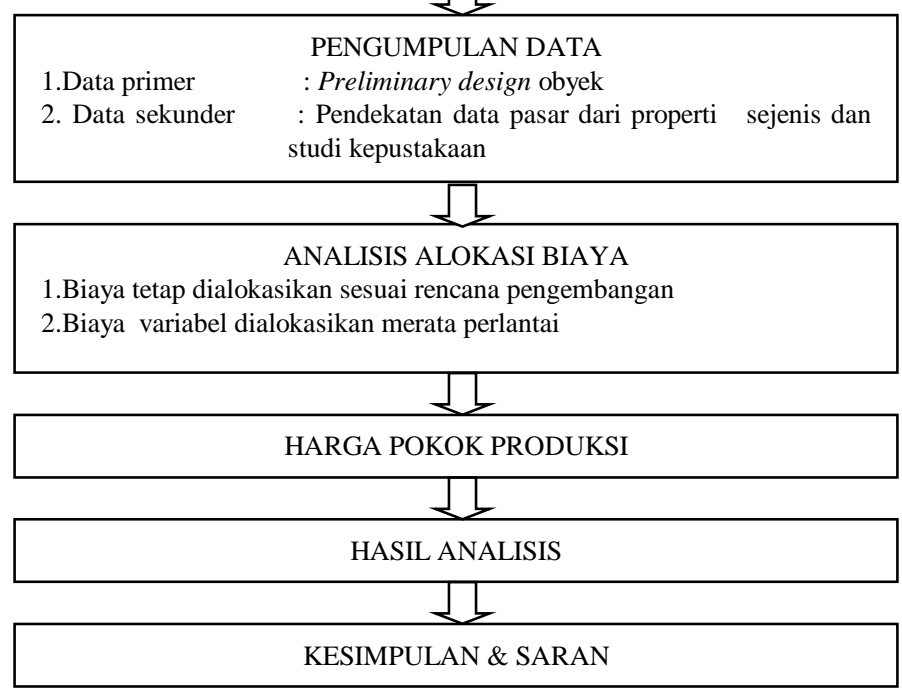

Gambar.2. Diagram Alir Penelitian

\section{ANALISIS DAN PEMBHASAN}

Pada bab ini akan dibahas hasil dari penelitian alokasi biaya tetap pada penetapan harga pokok produksi unit hunian di tower 2 dan tower 3 pada apartemen Tamansari Prospero Sidoarjo, Jawa Timur.

\section{A. Identifikasi Biaya}

Biaya-biaya yang dikeluarkan untuk membangun unit hunian di Tower 2 dan 3 Apartemen Tamansari Prospero diidentifikasi berdasarkan rencana pembangunan obyek yang terlebih dahulu membangun semua pendukung unit hunian. Sedangkan arsitektur unit hunian maupun interior didalamnya dikerjakan apabila unit hunian sudah terjual. Setelah 
diidentifikasi biaya-biaya kemudian dikelompokkan menjadi biaya tetap dan biaya variabel seperti Tabel 1.

Tabel 1.

Identifikasi Biaya

\begin{tabular}{|c|l|c|}
\hline No & \multicolumn{1}{|c|}{ Uraian Elemen Biaya } & Identifikasi Biaya \\
\hline 1 & Biaya pengadaan Lahan & Biaya Tetap \\
\hline 2 & Biaya pek. semibasement & Biaya Tetap \\
\hline 3 & Biaya substruktur (pondasi) & Biaya Tetap \\
\hline 4 & Biaya pekerjaan struktur & Biaya Tetap \\
\hline 5 & Biaya arsitektur area komersial (lt 1-5) & Biaya Tetap \\
\hline 6 & $\begin{array}{l}\text { Biaya arsitektur area bersama lt hunian (koridor hunian, } \\
\text { area lift)(lt 6-27) }\end{array}$ & Biaya Tetap \\
\hline 7 & Biaya arsitektur unit hunian (lt 6-27) & Biaya Variabel \\
\hline 8 & Biaya interior unit hunian (lt 6-27) & Biaya Variabel \\
\hline 9 & Biaya pek.utilitas (MEP) & Biaya Tetap \\
\hline 10 & Biaya pek lift & Biaya Tetap \\
\hline 11 & Biaya pekerjaan kolam renang & Biaya Tetap \\
\hline 12 & Biaya komponen kegiatan & Biaya Tetap \\
\hline
\end{tabular}

Sumber : Hasil Perhitungan

\section{B. Biaya Tetap}

Biaya tetap adalah biaya-biaya yang besarnya tidak dipengaruhi oleh volume produksi [13]. Biaya tetap pada Apartemen Tamansari Prospero ini meliputi :

Tabel 2.

Perhitungan Biaya Tetap Sebelum Alokasi

\begin{tabular}{|c|c|c|c|c|}
\hline \multirow[t]{2}{*}{ No } & \multirow[t]{2}{*}{ Uraian Elemen Biaya Tetap } & \multicolumn{3}{|c|}{ Total Biaya (Rp) } \\
\hline & & Tower 2 & Tower 3 & Podium \\
\hline 1 & Biaya pengadaan Lahan & 12.860 .746 .224 & 12.860 .746 .224 & 18.699 .505 .665 \\
\hline 2 & Biaya pek. semibasement & - & - & 1.868.030.102 \\
\hline 3 & Biaya substruktur (pondasi) & 4.886.896.618 & 5.198 .218 .839 & 4.670 .075 .255 \\
\hline 4 & Biaya pekerjaan struktur & 18.733.103.704 & 19.926.505.549 & 18.680 .301 .021 \\
\hline 5 & Biaya arsitektur area komersial (It 1-5) & 2.610 .111 .344 & 3.404 .709 .280 & 38.294.617.094 \\
\hline 6 & $\begin{array}{l}\text { Biaya arsitektur area bersama It hunian (koridor hunian, } \\
\text { area lift)(lt 6-27) }\end{array}$ & 6.869 .080 .384 & 6.973.134.911 & - \\
\hline 7 & Biaya pek.utilitas (MEP) & 17.918.620.934 & 18.193.765.936 & 23.350 .376 .277 \\
\hline 8 & Biaya pek lift & 2.443.448.309 & 2.599.109.419 & 3.736 .060 .204 \\
\hline 9 & Biaya pekerjaan kolam renang & - & - & 2.802 .045 .153 \\
\hline 10 & Biaya komponen kegiatan & 6.662 .469 .057 & 7.086.905.017 & 7.640 .243 .118 \\
\hline & TOTAL & 72.984.476.574 & 76.243.095.175 & 119.741 .253 .889 \\
\hline
\end{tabular}

Sumber : Hasil Perhitungan

\section{Biaya Variabel}

Jumlah biaya variabel berubah mengikuti tingkat aktivitas atau cost driver [14]. Biaya variabel (variable cost) dapat pula diartikan sebagai biaya-biaya yang yang secara proporsional dipengaruhi oleh jumlah output [13]. Biaya variabel pada Apartemen Tamansari Prospero meliputi :

Tabel 3.

Perhitungan Biaya Variabel Sebelum Alokasi

\begin{tabular}{|c|c|c|c|}
\hline \multirow[t]{2}{*}{ No } & \multirow{2}{*}{ Uraian Elemen Biaya Tetap } & \multicolumn{2}{|c|}{ Total Biaya $(\mathrm{Rp})$} \\
\hline & & Tower 2 & Tower 3 \\
\hline 1 & Biaya arsitektur unit hunian (It 6-27) & 15.769 .774 .135 & 14.746.880.197 \\
\hline 2 & Biaya interior unit hunian (It 6-27) & 12.217.241.546 & 15.594.656.517 \\
\hline & TOTAL & 27.28 .015 .081 & 30.341 .536 .714 \\
\hline
\end{tabular}

Sumber : Hasil Perhitungan

\section{Alokasi Biaya Tetap}

Pembebanan alokasi biaya dengan menggunakan metode pembebanan tarif ganda yaitu dengan melakukan pembebanan biaya tetap dan biaya variabel. Berdasarkan rencana pengembangan untuk obyek ini, biaya tetap yaitu biaya pengadaan lahan, pekerjaan semi basement, pondasi, biaya pekerjaan struktur, biaya arsitektur area komersial lantai 1-5 tower, biaya arsitektur bersama lantai hunian, biaya MEP, dan biaya komponen kegiatan perlu dialokasikan dengan pembebanan biaya yang berbeda sesuai dengan rencana pengembangan seperti pada Gambar 3 .

Alokasi biaya tetap dilakukan dengan 3 tahap. Alokasi biaya tetap area residensial ke area komersial, alokasi biaya lift dan alokasi biaya kolam renang sesuai dengan posisi unit secara vertikal maupun horizontal.

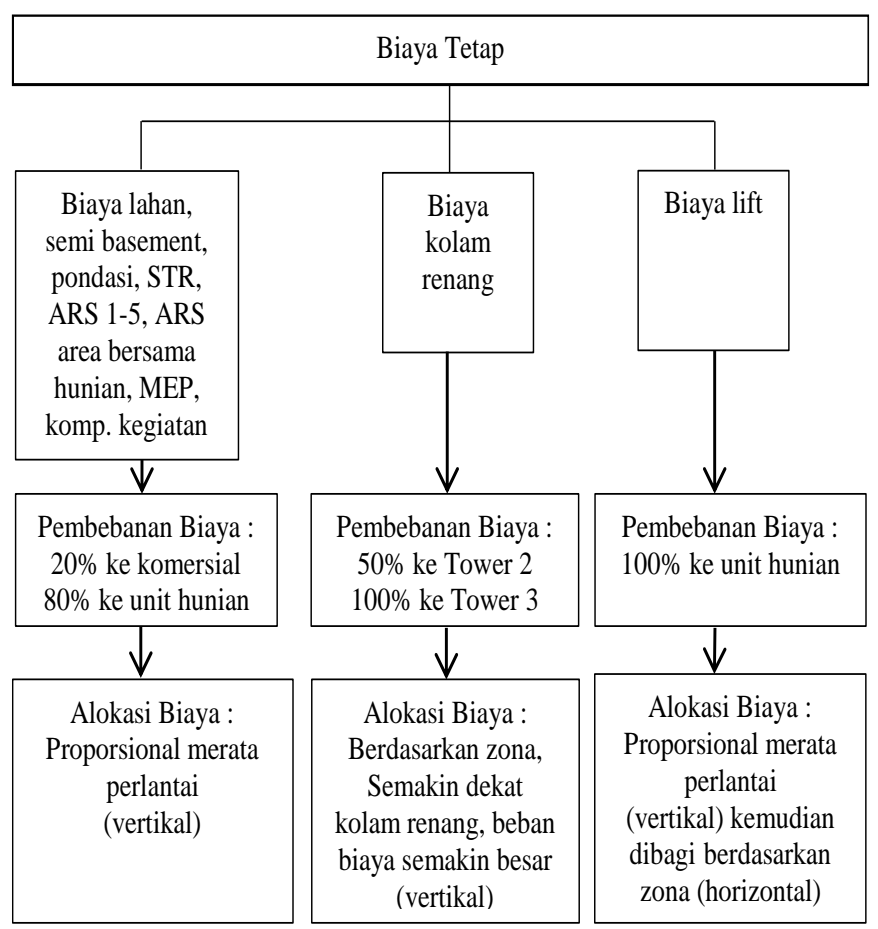

Gambar.3. Diagram Alir Alokasi Biaya Tetap

Alokasi biaya tetap meliputi 3 hal :

1. Alokasi biaya tetap hunian ke area komersial

Sebesar 20\% dari biaya tetap hunian dialokasikan ke area komersial kecuali lift dan kolam renang seperti Tabel 4.

Tabel 4.

Alokasi biaya hunian ke area komersial

\begin{tabular}{|l|l|c|c|}
\hline \multirow{2}{*}{ No } & \multicolumn{1}{|c|}{ Uraian Biaya } & \multicolumn{2}{c|}{ Total Biaya (Rp) } \\
\cline { 2 - 4 } & & 12.860 .746 .224 & 12.860 .746 .224 \\
\hline 1 & Biaya pengadaan Lahan & 4.886 .896 .618 & 5.198 .218 .839 \\
\hline 2 & Biaya substruktur (pondasi) & 18.733 .103 .704 & 19.926 .505 .549 \\
\hline 3 & Biaya pekerjaan struktur & 2.610 .111 .344 & 3.404 .709 .280 \\
\hline 4 & Biaya arsitektur area komersial (lt 1-5) & 6.869 .080 .384 & 6.973 .134 .911 \\
\hline 5 & $\begin{array}{l}\text { Biaya arsitektur area bersama lt hunian } \\
\text { (koridor hunian, area lift)(lt 6-27) }\end{array}$ & 17.918 .620 .934 & 18.193 .765 .936 \\
\hline 6 & Biaya pek.utilitas (MEP) & 6.662 .469 .057 & 7.086 .905 .017 \\
\hline 7 & Biaya komponen kegiatan & $\mathbf{7 0 . 5 4 1 . 0 2 8 . 2 6 5}$ & $\mathbf{7 3 . 6 4 3 . 9 8 5 . 7 5 6}$ \\
\hline & TOTAL BIAYA TETAP & $20 \%$ & $20 \%$ \\
\hline & Bobot pembebanan biaya (\%) & 14.108 .205 .653 & 14.728 .797 .151 \\
\hline & Nilai biaya yang dibebankan ke podium & 56.432 .822 .612 & 58.915 .188 .605 \\
\hline & Nilai total biaya tetap yang disebar merata & $\mathbf{2 . 5 6 5 . 1 2 8 . 3 0 1}$ & $\mathbf{2 . 6 7 7 . 9 6 3 . 1 1 8}$ \\
\hline & Nilai alokasi biaya tetap per lantai & & \\
\hline
\end{tabular}

Sumber : Hasil Perhitungan

\section{Alokasi biaya kolam renang}

Kolam renang merupakan fasilitas yang hanya dapat diakses oleh penghuni unit apartemen, oleh karena itu biayanya dialokasikan ke unit apartemen secara vertikal dengan rincian seperti pada Tabel 5 dan Tabel 6 : 
Tabel 5.

Pembagian zona alokasi biaya kolam renang

\begin{tabular}{|c|c|c|c|}
\hline Pembagian Zona & Lokasi & Jumlah Lantai & Bobot Biaya \\
\hline Zona 1 & Lt 6-12 & 7 & $50 \%$ \\
\hline Zona 2 & Lt 13-19 & 7 & $35 \%$ \\
\hline Zona 3 & Lt 20-27 & 8 & $15 \%$ \\
\hline TOT AL & & 22 & $100 \%$ \\
\hline
\end{tabular}

Sumber : Hasil Perhitungan

Tabel 6.

Rekapitulasi Alokasi Biaya Kolam Renang.

\begin{tabular}{|c|c|c|c|c|c|c|}
\hline \multirow[t]{2}{*}{ Zona } & \multirow[t]{2}{*}{$\mathrm{Lt}$} & \multirow{2}{*}{$\begin{array}{l}\text { Bobot } \\
\text { Alokasi }\end{array}$} & \multicolumn{2}{|c|}{ Tower 2} & \multicolumn{2}{|c|}{ Tower 3} \\
\hline & & & $\begin{array}{l}\text { Alokasi Biaya } \\
\text { (Rp) }\end{array}$ & $\begin{array}{l}\text { Biaya per } \\
\text { m2 (Rp) }\end{array}$ & $\begin{array}{l}\text { Alokasi Biaya } \\
\quad(\mathrm{Rp})\end{array}$ & $\begin{array}{c}\text { Biaya per } \\
\mathrm{m} 2(\mathrm{Rp})\end{array}$ \\
\hline \multirow{7}{*}{ స్ّ̆ } & 6 & $50 \%$ & 100.073 .041 & 179.463 & 200.146 .082 & 358.926 \\
\hline & 7 & $50 \%$ & 100.073 .041 & 179.463 & 200.146 .082 & 358.926 \\
\hline & 8 & $50 \%$ & 100.073 .041 & 179.463 & 200.146 .082 & 358.926 \\
\hline & 9 & $50 \%$ & 100.073 .041 & 179.463 & 200.146 .082 & 358.926 \\
\hline & 10 & $50 \%$ & 100.073 .041 & 179.463 & 200.146 .082 & 358.926 \\
\hline & 11 & $50 \%$ & 100.073 .041 & 179.463 & 200.146 .082 & 358.926 \\
\hline & 12 & $50 \%$ & 100.073 .041 & 179.463 & 200.146 .082 & 358.926 \\
\hline \multirow{7}{*}{$\begin{array}{l}\text { N } \\
\stackrel{\Xi}{0} \\
\text { N }\end{array}$} & 13 & $35 \%$ & 70.051 .129 & 125.624 & 140.102 .258 & 251.248 \\
\hline & 14 & $35 \%$ & 70.051 .129 & 125.624 & 140.102 .258 & 251.248 \\
\hline & 15 & $35 \%$ & 70.051 .129 & 125.624 & 140.102 .258 & 251.248 \\
\hline & 16 & $35 \%$ & 70.051 .129 & 125.624 & 140.102 .258 & 251.248 \\
\hline & 17 & $35 \%$ & 70.051 .129 & 125.624 & 140.102 .258 & 251.248 \\
\hline & 18 & $35 \%$ & 70.051 .129 & 125.624 & 140.102 .258 & 251.248 \\
\hline & 19 & $35 \%$ & 70.051 .129 & 125.624 & 140.102 .258 & 251.248 \\
\hline \multirow{8}{*}{ 芯 } & 20 & $15 \%$ & 26.269 .173 & 47.109 & 52.538 .347 & 94.218 \\
\hline & 21 & $15 \%$ & 26.269 .173 & 47.109 & 52.538 .347 & 94.218 \\
\hline & 22 & $15 \%$ & 26.269 .173 & 47.109 & 52.538 .347 & 94.218 \\
\hline & 23 & $15 \%$ & 26.269 .173 & 47.109 & 52.538 .347 & 94.218 \\
\hline & 24 & $15 \%$ & 26.269 .173 & 47.109 & 52.538 .347 & 94.218 \\
\hline & 25 & $15 \%$ & 26.269 .173 & 47.109 & 52.538 .347 & 94.218 \\
\hline & 26 & $15^{c}$ & 26.269 .173 & 47.109 & 52.538 .347 & 94.218 \\
\hline & 27 & $15 \%$ & 26.269 .173 & 47.109 & 52.538 .347 & 94.218 \\
\hline
\end{tabular}

Sumber : Hasil Perhitungan

\section{Alokasi biaya lift}

Lift pada tower merupakan fasilitas yang hanya dapat diakses oleh penghuni unit hunian apartemen, sehingga biayabiaya yang dikeluarkan untuk penyediaan lift dibebankan kepada unit hunian. Biaya lift dialokasikan dua tahap yaitu secara vertikal merata dan horizontal proposrional sesuai dengan jarak unit dengan lift seperti Tabel 7-Tabel 9.

Tabel 7.

Alokasi Vertikal Biaya Lift

\begin{tabular}{|c|c|c|}
\hline Uraian & Tower 2 & Tower 3 \\
\hline Total biaya lift (Rp) & 2.443.448.309 & 2.599 .109 .419 \\
\hline Biaya lift per lantai (Rp) & 111.065 .832 & 118.141 .337 \\
\hline Luas Lantai hunian per lantai (m2) & 557,625 & 557,625 \\
\hline
\end{tabular}

Sumber : Hasil Perhitungan
Tabel 8.

Alokasi Biaya Lift Tower 2

\begin{tabular}{|c|c|c|c|c|c|}
\hline \multirow{2}{*}{ LT } & \multirow{2}{*}{$\begin{array}{l}\text { Biaya lift per } \\
\text { lantai (vertikal) }\end{array}$} & \multicolumn{2}{|c|}{ Alokasi Lift Horizontal } & \multicolumn{2}{|c|}{ Biaya Lift/m2 (per lantai) } \\
\hline & & Zona A & Zona B & Zona A & Zona B \\
\hline & & $60 \%$ & $40 \%$ & $239,40 \mathrm{~m} 2$ & $318,225 \mathrm{~m} 2$ \\
\hline 6 & 111.065 .832 & 66.639 .499 & 44.426 .333 & 278.360 & 139.607 \\
\hline 7 & 111.065 .832 & 66.639 .499 & 44.426 .333 & 278.360 & 139.607 \\
\hline 8 & 111.065 .832 & 66.639 .499 & 44.426 .333 & 278.360 & 139.607 \\
\hline 9 & 111.065 .832 & 66.639 .499 & 44.426 .333 & 278.360 & 139.607 \\
\hline 10 & 111.065 .832 & 66.639 .499 & 44.426 .333 & 278.360 & 139.607 \\
\hline 11 & 111.065 .832 & 66.639 .499 & 44.426 .333 & 278.360 & 139.607 \\
\hline 12 & 111.065 .832 & 66.639 .499 & 44.426 .333 & 278.360 & 139.607 \\
\hline 13 & 111.065 .832 & 66.639 .499 & 44.426 .333 & 278.360 & 139.607 \\
\hline 14 & 111.065 .832 & 66.639 .499 & 44.426 .333 & 278.360 & 139.607 \\
\hline 15 & 111.065 .832 & 66.639 .499 & 44.426 .333 & 278.360 & 139.607 \\
\hline 16 & 111.065 .832 & 66.639 .499 & 44.426 .333 & 278.360 & 139.607 \\
\hline 17 & 111.065 .832 & 66.639 .499 & 44.426 .333 & 278.360 & 139.607 \\
\hline 18 & 111.065 .832 & 66.639 .499 & 44.426 .333 & 278.360 & 139.607 \\
\hline 19 & 111.065 .832 & 66.639 .499 & 44.426 .333 & 278.360 & 139.607 \\
\hline 20 & 111.065 .832 & 66.639 .499 & 44.426 .333 & 278.360 & 139.607 \\
\hline 21 & 111.065 .832 & 66.639 .499 & 44.426 .333 & 278.360 & 139.607 \\
\hline 22 & 111.065 .832 & 66.639 .499 & 44.426 .333 & 278.360 & 139.607 \\
\hline 23 & 111.065 .832 & 66.639 .499 & 44.426 .333 & 278.360 & 139.607 \\
\hline 24 & 111.065 .832 & 66.639 .499 & 44.426 .333 & 278.360 & 139.607 \\
\hline 25 & 111.065 .832 & 66.639 .499 & 44.426 .333 & 278.360 & 139.607 \\
\hline 26 & 111.065 .832 & 66.639 .499 & 44.426 .333 & 278.360 & 139.607 \\
\hline 27 & 111.065 .832 & 66.639 .499 & 44.426 .333 & 278.360 & 139.607 \\
\hline
\end{tabular}

Sumber : Hasil Perhitungan

Tabel 9.

Alokasi Biaya Lift Tower 3

\begin{tabular}{|r|c|c|c|c|}
\hline \multirow{2}{*}{$\begin{array}{c}\text { Biaya lift per } \\
\text { lantai (vertikal) }\end{array}$} & Zlokasi lift (Horizontal) & \multicolumn{2}{|c|}{ Biaya lift/m2 (horizontal) } \\
\hline & $60 \%$ & $40 \%$ & $239,40 \mathrm{~m} 2$ & $318,225 \mathrm{~m} 2$ \\
\hline 118.141 .337 & 70.884 .802 & 47.256 .535 & 296.094 & 148.500 \\
\hline 118.141 .337 & 70.884 .802 & 47.256 .535 & 296.094 & 148.500 \\
\hline 118.141 .337 & 70.884 .802 & 47.256 .535 & 296.094 & 148.500 \\
\hline 118.141 .337 & 70.884 .802 & 47.256 .535 & 296.094 & 148.500 \\
\hline 118.141 .337 & 70.884 .802 & 47.256 .535 & 296.094 & 148.500 \\
\hline 118.141 .337 & 70.884 .802 & 47.256 .535 & 296.094 & 148.500 \\
\hline 118.141 .337 & 70.884 .802 & 47.256 .535 & 296.094 & 148.500 \\
\hline 118.141 .337 & 70.884 .802 & 47.256 .535 & 296.094 & 148.500 \\
\hline 118.141 .337 & 70.884 .802 & 47.256 .535 & 296.094 & 148.500 \\
\hline 118.141 .337 & 70.884 .802 & 47.256 .535 & 296.094 & 148.500 \\
\hline 118.141 .337 & 70.884 .802 & 47.256 .535 & 296.094 & 148.500 \\
\hline 118.141 .337 & 70.884 .802 & 47.256 .535 & 296.094 & 148.500 \\
\hline 118.141 .337 & 70.884 .802 & 47.256 .535 & 296.094 & 148.500 \\
\hline 118.141 .337 & 70.884 .802 & 47.256 .535 & 296.094 & 148.500 \\
\hline 118.141 .337 & 70.884 .802 & 47.256 .535 & 296.094 & 148.500 \\
\hline 118.141 .337 & 70.884 .802 & 47.256 .535 & 296.094 & 148.500 \\
\hline 118.141 .337 & 70.884 .802 & 47.256 .535 & 296.094 & 148.500 \\
\hline 118.141 .337 & 70.884 .802 & 47.256 .535 & 296.094 & 148.500 \\
\hline 118.141 .337 & 70.884 .802 & 47.256 .535 & 296.094 & 148.500 \\
\hline 118.141 .337 & 70.884 .802 & 47.256 .535 & 296.094 & 148.500 \\
\hline 118.141 .337 & 70.884 .802 & 47.256 .535 & 296.094 & 148.500 \\
\hline 118.141 .337 & 70.884 .802 & 47.256 .535 & 296.094 & 148.500 \\
\hline Z & & & \\
\hline
\end{tabular}

Sumber : Hasil Perhitungan

\section{E. Biaya Total Pembangunan Unit Apartemen}

Biaya total dalam pembangunan unit apartemen yaitu biaya tetap yang sudah dialokasikan sesuai dengan posisi unit ditambahkan dengan biaya variabel dari masing-masing tipe unit hunian apartemen seperti pada Tabel 10 dan Tabel 11. 
Tabel 10.

Biaya Total Unit Apartemen Tower 2

\begin{tabular}{|c|c|c|c|c|}
\hline \multirow{2}{*}{$\begin{array}{c}\text { Biaya Total } \\
\text { (Tower 2) }\end{array}$} & \multicolumn{4}{|c|}{ LUAS MASING-MASING TIPE HUNIAN } \\
\hline & studio & $1 \mathrm{BR}-\mathrm{A}$ & $1 \mathrm{BR}-\mathrm{B}$ & $2 \mathrm{BR}$ \\
\hline Zona 1A & 125.501 .479 & 188.252 .218 & - & 251.002 .957 \\
\hline Zona 2A & 124.580 .834 & 186.871 .250 & - & 249.161 .667 \\
\hline Zona $3 \mathrm{~A}$ & 123.238 .226 & 184.857 .339 & - & 246.476 .452 \\
\hline Zona 1B & 123.128 .788 & 184.693 .183 & 198.194 .146 & 246.257 .577 \\
\hline Zona 2B & 122.208 .143 & 183.312 .215 & 196.712 .231 & 244.416 .287 \\
\hline Zona 3B & 120.865 .536 & 181.298.304 & 194.551 .104 & 241.731 .072 \\
\hline
\end{tabular}

Sumber : Hasil Perhitungan

Tabel 11.

Biaya Total Unit Apartemen Tower 3

\begin{tabular}{|l|c|c|c|c|c|}
\hline \multirow{2}{*}{$\begin{array}{c}\text { Biaya Total } \\
\text { (Tower 3) }\end{array}$} & \multicolumn{6}{|c}{ LUAS MASING-MASING TIPE HUNIAN } & \\
\hline Zona 1A & 135.615 .662 & 203.423 .492 & - & 271.231 .323 & 406.846 .985 \\
\hline Zona 2A & 133.774 .372 & 200.661 .557 & - & 267.548 .743 & 401.323 .115 \\
\hline Zona 3A & 131.089 .157 & 196.633 .735 & - & 262.178 .314 & 393.267 .470 \\
\hline Zona 1B & 133.091 .818 & 199.637 .727 & 214.231 .128 & 266.183 .636 & 399.275 .454 \\
\hline Zona 2B & 131.250 .528 & 196.875 .792 & 211.267 .297 & 262.501 .056 & 393.751 .584 \\
\hline Zona 3B & 128.565 .313 & 192.847 .970 & 206.945 .044 & 257.130 .626 & 385.695 .939 \\
\hline
\end{tabular}

Sumber : Hasil Perhitungan

\section{F. Harga Pokok Produksi Unit Hunian Apartemen}

Biaya-biaya yang dikeluarkan untuk pembangunan unit hunian apartemen akan dikembalikan oleh harga pokok produksi dengan laba yang diingankan. Dalam penelitian ini, disimulasikan laba yang diinginkan sebesar 10\%, 20\%, 30\% untuk masing-masing tipe unit hunian, yang terdapat di pada Tabel.12 - Tabel.17.

Tabel 12

Rekapitulasi HPP Unit Tower 2 Laba

\begin{tabular}{l|c|c|c|c|}
\hline \multirow{2}{*}{$\begin{array}{c}\text { HPP (Tower 2) } \\
\text { laba 10\% }\end{array}$} & \multicolumn{4}{c}{ LUAS MASING-MASING TIPE HUNIAN } \\
\hline Zona 1a & 138.051 .626 & 207.077 .440 & - & 276.103 .253 \\
\hline Zona 2a & 137.038 .917 & 205.558 .375 & - & 274.077 .834 \\
\hline Zona 3a & 135.562 .049 & 203.343 .073 & - & 271.124 .098 \\
\hline Zona 1b & 135.441 .667 & 203.162 .501 & 218.013 .561 & 270.883 .335 \\
\hline Zona 2b & 134.428 .958 & 201.643 .437 & 216.383 .454 & 268.857 .915 \\
\hline Zona 3b & 132.952 .090 & 199.428 .134 & 214.006 .214 & 265.904 .179 \\
\hline
\end{tabular}

Tabel 13

Rekapitulasi HPP Unit Tower 2 Dengan Laba 20\%

\begin{tabular}{|l|c|c|c|c|}
\hline \multirow{2}{*}{$\begin{array}{l}\text { HPP (Tower 2) } \\
\text { laba 20\% }\end{array}$} & \multicolumn{4}{c|}{ LUAS MASING-MASING TIPE HUNIAN } \\
\hline Zona 1a & 150.601 .774 & 225.902 .661 & & 301.203 .549 \\
\hline Zona 2a & 149.497 .000 & 224.245 .500 & - & 298.994 .001 \\
\hline Zona 3a & 147.885 .871 & 221.828 .807 & - & 295.771 .743 \\
\hline Zona 1b & 147.754 .546 & 221.631 .819 & 237.832 .976 & 295.509 .092 \\
\hline Zona 2b & 146.649 .772 & 219.974 .658 & 236.054 .677 & 293.299 .544 \\
\hline Zona 3b & 145.038 .643 & 217.557 .965 & 233.461 .325 & 290.077 .286 \\
\hline
\end{tabular}

Tabel 14.

Rekapitulasi HPP Unit Tower 2 Dengan Laba 30\%

\begin{tabular}{|l|c|c|c|c|}
\hline \multirow{2}{*}{$\begin{array}{c}\text { HPP (Tower 2) } \\
\text { laba 30\% }\end{array}$} & \multicolumn{4}{|c}{ LUAS MASING-MASING TIPE HUNIAN } \\
\hline Zona 1a & 163.151 .922 & 244.727 .883 & & 326.303 .844 \\
\hline Zona 2a & 161.955 .084 & 242.932 .625 & - & 323.910 .167 \\
\hline Zona 3a & 160.209 .694 & 240.314 .541 & - & 320.419 .388 \\
\hline Zona 1b & 160.067 .425 & 240.101 .137 & 257.652 .390 & 320.134 .850 \\
\hline Zona 2b & 158.870 .586 & 238.305 .880 & 255.725 .900 & 317.741 .173 \\
\hline Zona 3b & 157.125 .197 & 235.687 .795 & 252.916 .435 & 314.250 .394 \\
\hline
\end{tabular}

Tabel 15.

Rekapitulasi HPP Unit Tower 3 Dengan Laba 10\%

\begin{tabular}{|l|c|c|c|c|c|}
\hline HPP (Tower 3) & \multicolumn{5}{c}{ LUAS MASING-MASING TIPE HUNIAN } \\
\cline { 2 - 7 } Laba 10\% & studio & 1 BR-A & 1 BR-B & 2 BR & 3 BR \\
\hline Zona 1a & 149.177 .228 & 223.765 .842 & - & 298.354 .456 & 447.531 .683 \\
\hline Zona 2a & 147.151 .809 & 220.727 .713 & - & 294.303 .617 & 441.455 .426 \\
\hline Zona 3a & 144.198 .072 & 216.297 .109 & - & 288.396 .145 & 432.594 .217 \\
\hline Zona 1b & 146.401 .000 & 219.601 .500 & 235.654 .241 & 292.802 .000 & 439.203 .000 \\
\hline Zona 2b & 144.375 .581 & 216.563 .371 & 232.394 .027 & 288.751 .161 & 433.126 .742 \\
\hline Zona 3b & 141.421 .844 & 212.132 .767 & 227.639 .548 & 282.843 .689 & 424.265 .533 \\
\hline
\end{tabular}

Tabel 16.

Rekapitulasi HPP Unit Tower 3 Dengan Laba 20\%

\begin{tabular}{|l|c|c|c|c|c|}
\hline HPP (Tower 3) & \multicolumn{5}{c}{ LUAS MASING-MASING TIPE HUNIAN } \\
\cline { 2 - 7 } Laba 20\% & studio & 1 BR-A & 1 BR-B & 2 BR & 3 BR \\
\hline Zona 1a & 162.738 .794 & 244.108 .191 & - & 325.477 .588 & 488.216 .382 \\
\hline Zona 2a & 160.529 .246 & 240.793 .869 & - & 321.058 .492 & 481.587 .737 \\
\hline Zona 3a & 157.306 .988 & 235.960 .482 & - & 314.613 .976 & 471.920 .964 \\
\hline Zona 1b & 159.710 .182 & 239.565 .272 & 257.077 .354 & 319.420 .363 & 479.130 .545 \\
\hline Zona 2b & 157.500 .634 & 236.250 .950 & 253.520 .757 & 315.001 .267 & 472.501 .901 \\
\hline Zona 3b & 154.278 .376 & 231.417 .564 & 248.334 .052 & 308.556 .752 & 462.835 .127 \\
\hline
\end{tabular}

Tabel 17.

Rekapitulasi HPP Unit Tower 3 Dengan Laba 30\%

\begin{tabular}{|c|c|c|c|c|c|}
\hline HPP (Tower 3) & \multicolumn{5}{c}{ LUAS MASING-MASING TIPE HUNIAN } \\
\hline Laba 30\% & studio & 1 BR-A & 1 BR-B & 2 BR & 3 BR \\
\hline Zona 1a & 176.300 .360 & 264.450 .540 & - & 352.600 .720 & 528.901 .080 \\
\hline Zona 2a & 173.906 .683 & 260.860 .024 & - & 347.813 .366 & 521.720 .049 \\
\hline Zona 3a & 170.415 .904 & 255.623 .856 & - & 340.831 .808 & 511.247 .711 \\
\hline Zona 1b & 173.019 .363 & 259.529 .045 & 278.500 .467 & 346.038 .727 & 519.058 .090 \\
\hline Zona 2b & 170.625 .686 & 255.938 .529 & 274.647 .486 & 341.251 .373 & 511.877 .059 \\
\hline Zona 3b & 167.134 .907 & 250.702 .361 & 269.028 .557 & 334.269 .814 & 501.404 .721 \\
\hline
\end{tabular}

\section{KESIMPULAN/RINGKASAN}

Berdasarkan hasil analisis dan pembahasan di bab sebelumnya, dapat ditarik kesimpulan harga pokok produksi (HPP) dengan melakukan alokasi biaya tetap berdasarkan posisi unit dan laba yang diingnkan, menghasilkan harga pokok unit hunian Tower 2 dan Tower 3 yang berbeda-beda.

HPP unit hunian di Tower 2, yaitu tipe studio berkisar 132jt-163jt. Tipe 1BR-A berkisar 199jt-244jt. Tipe 1BR-B berkisar 214jt-257jt. Tipe 2BR sekitar 265jt-326jt. HPP untuk tipe unit hunian di Tower 3, yaitu tipe studio berkisar $141 \mathrm{jt}$ 176jt. Tipe 1BR-A, 212jt-264 jt. Tipe 1BR-B, berkisar $227 \mathrm{jt}-$ 278jt. Tipe 2BR, berkisar 282jt-352jt, dan 3BR berkisar $424 \mathrm{jt}-$ $528 \mathrm{jt}$.

\section{DAFTAR PUSTAKA}

[1] Putra, M.A.A., Nurcahyo, C.B., dan Utomo, C. 2013. Analisis Pembeayaan Investasi Proyek Apartemen Puncak Kertajaya. Jurnal Teknik ITS Vol. 2, No. 1 D1-D5. Institut Teknologi Sepuluh Nopember Surabaya.

[2] Wahyudhi, O.O., Utomo, C. 2014. Analisis Investasi pada Proyek Pembangunan Apartemen Bale Hinggil Surabaya. Jurnal Teknik ITS Vol. 3, No. 1 D41-D46. Institut Teknologi Sepuluh Nopember Surabaya.

[3] Ningsih, M.D.P., Utomo, C. 2014. Analisis Pembiayaan Investasi Apartemen Puri Park View Tower E Kebon Jeruk - Jakarta Barat. Jurnal Teknik ITS Vol. 3, No. 2 D104-D108. Institut Teknologi Sepuluh Nopember Surabaya.

[4] Maulina, Z.P., Utomo, C. 2015. Study Kelayakan Investasi Apartemen Gunawangsa Merr Surabaya. Jurnal Teknik ITS Vol. 4, No. 2 1-5. Institut Teknologi Sepuluh Nopember Surabaya.

[5] Fahad dan Utomo, C. 2013. Analisis Penetapan Harga Jual Unit Rumah pada Proyek Perumahan Soka Park Bangkalan. Jurnal Teknik ITS Vol. 2 No. 2 C173-C177. Institut Teknologi Sepuluh Nopember Surabaya.

[6] Damayanti, R., dan Utomo, C. 2014. Analisis Biaya dan Permintaan pada Penetapan Harga Marginal Unit Rumah di Perumahan Royal Regency, Lumajang. Jurnal Teknik ITS Vol. 3 No. 1 D36-D40. Institut Teknologi Sepuluh Nopember Surabaya. 
[7] Hidayat, M.F., dan Utomo, C. 2014. Analisis Penetapan Harga Jual Unit Rumah di Perumahan Griya Agung Permata, Lamongan. Jurnal Teknik ITS Vol 3, No. 2 C57- C61. Institut Teknologi Sepuluh Nopember Surabaya.

[8] Septiantoro, U.O dan Utomo, C. 2015. Analisis Penetapan Harga Jual Unit Rumah Pada Proyek Perumahan Griya Suci Permai Baru, Gresik. Jurnal Teknik ITS Vol.4 No.1. D6-D10. Institut Teknologi Sepuluh Nopember Surabaya.

[9] Aprilia, W.I., dan Utomo, C. 2014. Analisis Penetapan Harga Jual Unit Apartemen Bale Hinggil di Surabaya. Jurnal Teknik ITS Vol. 3, No. 2 D59-D64. Institut Teknologi Sepuluh Nopember Surabaya.

[10] Utomo, T dan Utomo, C.2014. Penetapan Harga Pokok Penjualan Berdasarkan Alokasi Biaya Terhadap Posisi Rumah Pada Perumahan Green Park Residence Sampang. Jurnal Teknik ITS Vol. 3, No. 2 C76-C80. Institut Teknologi Sepuluh Nopember Surabaya.

[11] Hanundyasari, D dan Utomo, C. 2014. Analisis Penetapan Harga Pokok Penjualan Apartemen Puri Park View Tower E Kebon Jeruk Jakarta Barat. Jurnal Teknik ITS Vol. 3, No. 2 D147-D152. Institut Teknologi Sepuluh Nopember. Surabaya.

[12] Sembiring, G.E.S., dan Utomo, C. 2015. Analisis Biaya Tetap dan Biaya Variabel Pada Penetapan Harga Pokok Sewa Apartemen di Yogyakarta. Jurnal Teknik ITS Vol.4 No.2. C59-C64. Institut Teknologi Sepuluh Nopember Surabaya.

[13] Pujawan, I.N. 1995. Ekonomi Teknik. Edisi Pertama. Surabaya : Guna Widya.

[14] Hilton, R.W. 1999. Managerial Accounting. United States of America : The McGraw.Hill Companies, Inc. 